\title{
WHITMAN ON “THE BLACK QUESTION": A NEW MANUSCRIPT
}

\author{
Geoffrey SiLL
}

WhitMAN's Misgivings ABOUT THE "PROBLEM" of the civil rights of blacks in the America that emerged from the Civil War have been the subject of several recent discussions, notably in Betsy Erkkila's Whitman the Polital Poet (1989) and Kenneth Price's article, "Whitman's Solutions to 'The Problem of the Blacks'" (1985). ${ }^{1}$ Erkkila concedes that Whitman was "not fully prepared to integrate the black person into his vision of a free and equal America" (240), and Price finds a contradiction between the persona of "Walt," who wrote Leaves of Grass, and Whitman the man, who "occasionally voiced racist beliefs" that he had picked up from his family and from contemporary science (206). A previously unknown manuscript by Whitman, recently obtained and made available for study by Whitman collector William Kurry, amplifies our knowledge of Whitman's attitudes on this crucial point, and dramatizes, through its extensive revisions, Whitman's struggle to resolve for himself the question of the blacks.

The manuscript, which is not included in Edward F. Grier's Walt Whitman: Notebooks and Unpublished Prose Manuscripts, ${ }^{2}$ is a single folio sheet about 10 inches in length (see facsimile on the back cover). In the final state in which Whitman left it, it reads as follows:

\section{Of the black question}

After the tender appeals of the sentimentalist, the eloquence of freedom's hottest orators, and the logic of the politico-economist, comes something else to the settlement of this question-comes Ethnological Science, cold, remorseless, not heeding at all the vehement abstractions of equality and fraternity, or any of the formulas thereof-uninfluenced by Acts of Congress, or Constitutional Amendmentsby noiselessly rolling on like the globe in its orbit, like summer's heat or winter's cold, and settling these things by evolution, by natural selection by certain races notwithstanding all the frantic pages of the sentimentalists helplessly disappearing by the slow, sure progress of laws, through sufficient periods of time.

The references in this paragraph to "Acts of Congress," or "Constitutional Amendments" having to do with the "black question" would seem to date the passage approximately in 1867, when Whitman was attending the debates in Congress that eventually led to the Reconstruction Acts and the Fourteenth and Fifteenth Amendments to the Consti- 
tuition, which granted citizenship and the franchise to former slaves. ${ }^{3}$ The reference to "freedom's hottest orators" seems to support this early date, since Thaddeus Stevens, the famous radical Republican who campaigned vigorously in the House of Representatives for the Reconstruction Acts, died in 1868. On the other hand, the reliance of the passage on the inevitable operation of natural laws to accomplish ends which cannot be achieved through human efforts seems to anticipate-if not encompass - the failure of the Reconstruction policy in 1876, as a result of which the civil rights of blacks in the South were largely lost.

Though the passage deals with the same subject as that of "The Problem of the Blacks" (the manuscript published and ably discussed by Kenneth Price in 1985), it possesses one striking difference. Price's manuscript is clearly Whitman's note to himself-a note toward an intended article or lecture on the rise of the new South. Though the note specifies that the message is to be an "encouraging" one, the tone of the note is hardly promising. Whitman sees clearly that the question of black citizenship is central to the future of the South, but of the three alternatives that he poses - that the blacks will either "ffilter through in time," or "gradually eliminate and disappear," or develop the "mental and moral qualities ... of a leading and dominant race," which he deems unlikely - none of them is a political solution requiring the sorts of social change that the Reconstruction Acts were intended to impose. All of them depend on gradual change affecting primarily the blacks themselves - that is, a few of the best and brightest will "filter through" on the basis of their accomplishments, or they will be assimilated (and their identity lost), or they will conquer, dominate, and supplant the former slaveholding power structure of the South - though, without the advantages of wealth and education, no amount of time seemed sufficient to bring this change about.

But if the Price manuscript seems a writer's notes to himself, which betrays his doubts even as he promises an upbeat message, the Kurry manuscript is unmistakably addressed to a public readership. Its tone is affirmative, it appears scornful of the weak measures of man-whether in the form of the "sentimentalist," the "hot" orator of freedom, or the logical political economist - and it announces confidently that the question will be settled in time by the operation of the laws of nature, working through evolution and natural selection as described by ethnological science, whether Reconstruction Acts succeed or fail. Indeed, the tone led the writer of the catalog notes for the sale of the manuscript to declare that the manuscript shows Whitman as "a fighter for the cause of the black man and for democracy itself." 4 But more careful readings of the manuscript, particularly a reading that includes the words Whitman excised from it, reveal that the doubts and misgivings he had privately confided to himself in the Price manuscript are still present in 
the Kurry manuscript, and may account for the fact that the Kurry manuscript was not included in Whitman's collections of his prose works.

To incorporate these excised words into a reading of the manuscript, we must look at an expanded version of the text, with all of its cancellations restored. In this form, the manuscript reads as follows:

1.

Of the black question

2.

Then Something else enters into the settlement

3. These things finally- After all the even of politieal questions

appeals

4. tenderness $\wedge$ of the sentimentalist, and the

and the logic of the politico-economist,

5. eloquence of freedom's hottest orators,

6. comes something else to the settlement of

7. this question-comes Ethnologic $\underline{\underline{\underline{\underline{S}}}}$ cience, cold,

8. remorseless, not

heeding vehement abstractions of

9. - not $\wedge$ at all by the logie of abstraet equality or any of the thereof-

10. and fraternity, and the formulas of the books

11. or but rolling on like the globe in its

12. eourse, like summer's heat \& winter's uninfluenced by

13. eold, utterly eareless of party platforms,

14. eeelesiastieal deerees, or even Acts of Congress,

15. or Constitutional Amendments. - - settling streh things

16. by the hardy genesis of some raees and

$$
\text { -noiselessly }
$$

17. A rolling on like the globe in its orbit, 
and

18. like summer's heat or winter's cold, $\wedge$ settling these

things

questions by

19. things by by evolution, by natural selection,

20. notwithstanding all the frantic pages of the sentimentalists

21 . by certain races $\wedge$ helplessly disappearing when brought

and

22. in eontaet with other raees, by the slow sure pro-

sufficient

23. gress of her laws, through $\wedge$ periods of time.

Perhaps the first thing we notice about the text is the heavy extent of the revisions. Of the total of 182 words that Whitman used in composing this paragraph, 72 -approximately $40 \%$ - have been cancelled, and of the 110 that survived, 32 were inserted between the lines, with a caret. That means that 104 of the 182 words-about $57 \%$-were either struck out or added after the first draft, which suggests two conclusions: that Whitman wrote this paragraph with publication in mind, not merely for his own use; and that he found the phrasing of a public statement on this issue to be very difficult. ${ }^{5} \mathrm{We}$ also notice that a strip of paper has been pasted on top of the original folio sheet, covering all the words between "orators" in line 5 and "heeding" in line 8 , on which Whitman has proclaimed, in a large bold hand, the advent of Ethnological Science to settle the race question, underscoring the initial letters with three brief lines to be sure the printer would set them in upper case type. If we should doubt that Whitman meant to allegorize and personify ethnologic science by capitalizing the term, our doubts are erased by the next two words - "cold, remorseless"-with which a stern and authoritative face is imposed on what was still, at the time, a rather undefined and rudimentary area of study. ${ }^{6}$ Paradoxically, though given a human face, "Ethnological Science" will settle the race question not in terms of human sentiment, rhetoric, or logic, but according to natural laws that can no more be stopped than the earth can be turned from its course, or the seasons can be given new climates.

What is perhaps most interesting about Whitman's evocation of this impersonal arbiter of human affairs, Ethnological Science, is the identity of the human faculties and ideals that it supplants. We have already speculated that radical reformers like Thaddeus Stevens might have been on Whitman's mind when he referred to "freedom's hottest orators," and we might suppose that the "sentimentalists" are abolitionist writers, perhaps even including his close friend, William Douglas 
O'Connor - with whom Whitman was to break over precisely this question in 1872-while the tag "politico-economist" would seem to fit Thomas Carlyle, with whom Whitman was then engaged in the polemic that became Democratic Vistas. It is to be expected that Whitman would prefer the operation of a scientific force to the misguided efforts of these individuals; it is much less to be expected that Whitman should praise Ethnological Science for "not heeding at all the vehement abstractions of equality and fraternity," given that these are two of the three ideals of the French Revolution, which Whitman had long regarded as a major inspiration of his poetry, and which he continued to praise to the end of his life. ${ }^{7}$ It would appear that, while Whitman was all in favor of liberty for blacks, equality and fraternity were another matter.

Let us return to that two-inch strip of paper pasted in on top of a portion of the manuscript. At the bottom of the strip, we can make out the words underneath, which Whitman attempted to insert again on lines 21 and 22 of the expanded transcript: "by certain races helplessly disappearing when brought in contact with other races." The fact that Whitman twice attempted to insert this thought into his paragraph, and twice cancelled it, suggests to me that he saw racial assimilation as the key to "the black question," and that he also saw that it was impossible for him to propose this solution in print. Neither the liberals (who, like Whitman, secretly shared some of Thomas Carlyle's fears about democracy), ${ }^{8}$ nor the radicals, who (like William Douglas O'Connor) supported Whitman as long as they thought he served the Reconstructionist political agenda, would have been pleased by the thought that the best hope for America was for all races to disappear as a result of being brought into contact with one another. To avoid this explicit statement of his beliefs-which, in the Price fragment, he had described as the hope that the blacks would "gradually eliminate and disappear, which is most likely though that termination is far off . . ." (205)-Whitman enlisted the aid of an impersonal, irresistible historical force-natural selection - and its human descriptive apparatus, ethnological science.

There is one last indicator that Whitman was not entirely comfortable with the line of thought he was pursuing here. The syntax of the final lines of the manuscript appears to build toward an emphatic ending, much as the stanzas of Whitman's poems do. The syntax keys on the word "by," the preposition of agency-that is, Whitman is looking for the agent by which the black question will be settled. Early in the paragraph, he had stipulated that it would not be settled by the appeals of the sentimentalist, by the rhetoric of the orator, by the logic of the politico-economist, "by the logic of absolute equality and fraternity," or by "any of the formulas of the books." Toward the end of the paragraph, where he is affirming that a positive agent will be found, his clauses take on a familiar verse pattern: 
by evolution,

by natural selection,

by certain races helplessly disappearing

by the slow sure progress of her laws,

through sufficient periods of time.

But having achieved a certain rhythm and periodicity to his clauses, Whitman felt it necessary to insert the qualifying phrase, "notwithstanding all the frantic pages of the sentimentalists" between the words "races" and "helplessly," which made nonsense of the paragraph and stripped it of any poetic power. It appears that Whitman was so defensive about the reaction of the "sentimentalists" to his suggestion that time, and not the passions of ideology, would heal the racial divisions in America that he was willing to sacrifice some of the poetry of his language in order to make his position less vulnerable to the criticisms he' anticipated.

It is probably pointless to speculate about the reasons why Whitman did not include this memorandum among his published prose works. As he himself noted (perhaps with some exaggeration), there were "thousands" of these memoranda that were lost in his lifetime for each one that was preserved. ${ }^{9}$ The fact that this one was preserved, however, and the heavy revision to which it was subjected indicate that this manuscript had more than casual significance to Whitman. Its content might have entitled it to a place in Democratic Vistas, where Whitman gauges the chances that America will be able to handle similar problems that were the legacy of the Civil War-the "labor question," the formation of a single national identity, the creation of a unified culture that allows diversity and individuality. In the opening moments of that essay, he promises to treat the question of universal suffrage-- "I will not gloss over the appaling dangers of universal suffrage in the United States"10 - but in fact it is only the question of women's suffrage that is dealt with. Whatever the reason, Whitman sent Democratic Vistas and all of his other prose writings to press without any explicit statement of his position on "the black question."

That is not to say, however, that the question did not remain in his thoughts. We see again and again in his poetry the traces of his belief that time and evolution would eventually bring the races closer together. To take one instance, we might recall these lines from the second stanza of "A Passage to India":

Lo, soul, seest thou not God's purpose from the first?

The earth to be spann'd, connected by network,

The races, neighbors, to marry and be given in marriage,

The oceans to be cross'd, the distant brought near,

The lands to be welded together. 
In these lines, and in this poem generally, Whitman sought to invoke the long historical view to resolve the contradictions between the idea of America and the realities of post-Civil War politics. What the manuscript "Of the black question" teaches us above all is that these contradictions were not trivial problems to which Whitman dashed off glib answers, but were the subject of prolonged and agonized meditations, out of which Whitman ultimately wrote some of his most profoundly moving poems. ${ }^{11}$

\section{Rutgers University, Camden}

\section{NOTES}

1 Betsy Erkkila, Whitman the Political Poet (New York: Oxford University Press, 1989); Kenneth Price, "Whitman's Solutions to 'The Problem of the Blacks,'" Resources for American Literary Study 15 (1985), 205-208.

2 Edward F. Grier, Walt Whitman: Notebooks and Unpublished Prose Manuscripts (New York: New York University Press, 1984).

3 Erkkila, 245.

4 The author and date of this sale catalog are, regrettably, unknown.

5 The frequency of revisions in this prose manuscript is approximately the same as in the poem "You Tides with Ceaseless Swell," where Whitman was struggling with problems of form as well as content. See my "You Tides with Ceaseless Swell': A Reading of the Manuscript," Walt Whitman Quarterly Review 6 (1989), 189-197.

6 For Whitman's views on evolutionary science, see Price, 207; Harold Aspiz, Walt Whitman and the Body Beautiful (Urbana: University of Illinois Press, 1985), 184-194; Newton Arvin, Whitman (New York: MacMillan, 1938), 31-33, 216-218.

7 Erkkila, 304; Whitman, Prose Works 1892, ed. Floyd Stovall (New York University Press, 1964), 2:528.

8 Erkkila, 247.

9 “Small Memoranda," Prose Works 1892, 2:610.

10 “Democratic Vistas," Prose Works 1892, 2:363.

11 The author wishes to thank Mr. William Kurry for his assistance in preparing this article. 